\title{
Why Did Cornwall Vote for Brexit? Assessing the Implications for EU Structural Funding Programmes
}

\begin{abstract}
In the 2016 referendum on UK EU membership, regions which benefitted from high levels of structural funds voted to leave the EU. This was unexpected given the Europeanisation processes expected of the funds in terms of identity and loyalty. Within this case study of Cornwall, we use qualitative methods to assess why this happened and the implications for future structural funding programmes. We find that the rationale behind the Brexit vote was less about the EU as an institution, but was a reflection of the deep levels of uncertainty, insecurity, and frustration that people felt about governance decisions, scarce resources, and the future for themselves and their children. This created a situation where people looked to the nation state for support and security, and were fearful of post-national forms of identification and governance. Consequently, EU support is imagined as being organised by 'elites', for elites, rather than benefitting local communities.

We suggest breaking down some of the barriers that have arisen through a participatory approach to development decision-making, greater flexibility to regional priorities, and forms of funding that individuals might apply to - such as a skills pot to facilitate easier access to further education and training.
\end{abstract}




\section{Introduction}

The decision of the UK on $23^{\text {rd }}$ June 2016 to vote in a referendum to leave the European Union raises two significant issues for the EU. Firstly, why did many of the regions that had - or continued to have - benefitted from large amounts of European Union Structural funding choose to vote to leave the EU. Arguably, these are precisely the regions which have witnessed first-hand the economic rationale to remain as a part of the Union. This question carries important implications for EU structural funding programmes across Europe in the future. In particular, why such a large amount of investment has not brought with it a commensurate level of support for the institution that has been its benefactor, and what needs to be done in order to change this situation in the future, in other regions. This indicates an urgent need to assess better how people feel about the impacts that it has had on their localities. Our principal focus in this paper is not an objective discussion about the real impacts of structural funding as traditionally measured by Gross Domestic Product (GDP) or labour market statistics, but on how these monies were perceived by residents of a beneficiary, Brexit voting region. This is because it is these perceptions (objectively real, or imagined) that underpin voting decisions. This study provides a qualitative addition to current (mainly quantitative) research seeking to understand voters decisions to Leave.

Our case study of Cornwall in the South West of the UK enables us to explore these questions, and search for solutions. The paper will be organised as follows. Firstly, we will discuss and assess the literature around the Brexit vote, which raises many questions about political culture and the kinds of Britain imagined and experienced by citizens. It also becomes apparent that the material about why Britain voted for Brexit has overlaps with the literature about European integration, and the project to develop a more European identity within member states. We contend that this provides an important space to explore the relationship between Brexit voters, the nation state, and their immediate communities; in order to understand more about the kinds of lives that they lead and the things that they consider to be important.

Next, we look at the material about the effectiveness of structural funding programmes across the EU. We find that these tend to be focussed heavily on the economic data and on operational or implementation kinds of questions, and miss an analysis of the human experience of development. We will address this through a case study of Cornwall, which has benefitted from the highest levels of structural funding since 1999. We argue that participants were able to justify their Brexit vote despite being a beneficiary region from the EU, by constructing narratives which claimed that structural funding was inefficiently spent, spent on things which had no impact on participants lives, or were spent on the 'wrong' things, failing to address local issues and priorities. This indicates a pressing need for more place-based work in the delivery of structural funding and economic development.

\section{Why did Britain Vote for Brexit?}

Much academic and popular discourse surrounding the Brexit vote focusses on a series of cleavages within contemporary Britain, and some literatures expand this to incorporate newly developing cleavages throughout Western nation states. The most obvious of these contemporary fracture lines lie with the gap between the rich and the poor (the left behind), the educated and those with low educational attainment, the old and the young (Harris and Charlton 2016; Arorsson and Zoega, 2016; 
Goodwin and Heath, 2016), or those unable to adapt to changing socio-economic conditions (Los et al. 2017).

However more latterly there is a growing problematisation of such universal assertions, leading to claims that identity played an important role in shaping voting rationale, and that some of these underpin the fracture lines mentioned above. For example, Dorling (2016) points out that $59 \%$ of Leave voters were from the middle classes, rather than the poor, 'left behind'. Inglehart and Norris (2017) find that younger cohorts adopt a very different value-set to some of the older generations, emphasising post-materialism and self-expression. According to the authors, this cultural shift has fostered more tolerance and approval of a diverse range of lifestyles, religions, cultures, and fundamental freedoms and rights. They claim that the populism behind Brexit indicates a backlash against changes in cultural norms. This theory has some support from Kauffmann (2016), who finds a fundamental difference in identities and values between Brexit and Remain voters, with the former displaying more authoritarian type characteristics clustered around aspects of fear, concern with safety, security, and a strong element of nostalgia or affection for times gone by. In other words, that there are strong cultural differences between those with socially liberal values, and those with conservative ones. That the British public never completely bought in to a sense of European identity exacerbated these issues (Curtice 2017).

This observed difference in values is mirrored in the academic debate around economics and suggests that there is a complex relationship between economic and identity based rationales for voting Leave. The concept of the Left Behind rests on the notion that some people have 'won' in an era of economic globalisation, high mobility, and cosmopolitan values (Los et al. 2017; Becker et al. 2016). This narrative had particular salience with calls to 'take our country back' by voting Leave, and was more likely to be hostile to immigration which has become perceived as a threat to the economies and livelihoods of ordinary working people (Travers, 2016). The interesting thing here is the choice of target, or the rationale underneath such a Brexit vote. The reason for a lack of control to either borders (with respect to migration) or to economic inequality is laid squarely as the result of the European Union through both its regulatory mechanisms and because of its policy of open borders and unimpeded migration between member states. One source of frustration amongst British voters is the fact that Britain is one of the most unequal nations in the OECD with stark differences between wealthy regions and underperforming ones (McCann, 2016), and the booming London economy has not been able to positively impact other parts of the UK. Indeed, some parts of the UK still qualify for the highest levels of European Union Structural Funds, given to the very poorest parts of the EU (see below). Finally, Britain had just experienced six years of austerity - severe public sector cuts which has had a large impact on the kinds of services that are available to both working and middle classes (Travers, 2016).

However, rather than blaming the British government for policy problems, economic inequalities, poor access to services, and an over-centralised political system, two interlinked groups have received much of the blame: Immigrants and the EU. What this means is that the EU has discursively become a scape-goat, or 'other', to act as the repository for the perceived or real difficulties that British people face. As yet, we have not had an interpretive debate about Brexit that explores what understanding voter rationale means for contemporary policy.

\section{EUROPEAN INTEGRATION}


In Britain, clearly the European integration project of increased cooperation and harmonisation between member states has failed, and is under threat in other parts of the EU too. Consequently, support for anti-EU groups and discourses has risen significantly, and has been combined with a return to nationalist type policies and an othering of certain groups in society (Arzrout and Wojcieszak, 2017; Polyakova and Fligstein, 2016). Europeanisation describes and analyses the process through which EU ideas and policies diffuse across member states through sharing and emulating best practice (Borzel and Risse, 2012). As a process, new ideas need to become 'endogenised' within member states, which also raises questions about political agency (Radielli 2004). There are two separate ideas from the Europeanisation literature which add an extra texture to the analysis of Brexit, and are helpful for understanding better the context in which a region like Cornwall could vote for Brexit.

The first is the discussion around national versus European identification, which is epitomised by the Habermassian argument that the European tension between State and European citizenship presents itself as a form of 'divided sovereignty' (Habermas, 2017; Klaus, 2017). Here, nation States form a kind of 'natural' locus for individuals to coalesce around, bound together by shared identity. This claim recalls and derives from the earliest inception of the Modern Liberal nation state as the protector of individual liberties, rights and freedoms (Hampshire-Monk, 1991). Rousseau in particular discusses the need of the modern state to foster some form of shared identification as a means to aid governance and foster consent. As we know from the history of the modern nation (Smith, 1991), there were very few 'natural' states. Instead, state-building or nation-building was a (sometimes lengthy) process of identity construction. At times, such as in the Balkans in the 1990's, this process can go very badly wrong. What this is intended to show is that there is nothing 'natural' about the modern state as a locus of identification, which just like the current process of EU integration, also had to be artificially constructed (see also Klaus, 2017).

What might be imagined as different between European governance identities and national identities is that at this point, European citizenship follows a post-national, cosmopolitan type of identification, on top of national citizenship and identification (Zhan and Lille, 2015). This requires trust of, and in other European citizens and institutions (Hooghe and Verhaegen, 2017) and an openness and extraversion (Curtis, 2016). Realising the cosmopolitanism within the European project emphasises the value-differences behind Brexit voters. Largely, this group was wary of cosmopolitan values, turning towards national identification, evident in discourses around sovereignty and taking back control. Polyakova and Fligstein (2016) might explain this as being about the response of citizens experiencing some form of crisis (for example, the hardships caused by Austerity) to look to their national government as the place to provide protection and security.

The second idea that the Integration literature provides, is about the capacity of the EU to wield soft power through its institutions to effect some form of value shift which fosters European identification (Kouri, 2014) and local 'ownership' of EU strategic priorities (Mendez and Bachtler, 2016). This kind of mechanism needs to be both bottom up, but also top-down through increased visibility of EU institutions. Dabrowski (2012) argues that instruments such as cohesion policy provide one such example of this as recipients are required to follow a series of policy norms which develops some adjustment and socialisation of the region or nation-state towards European values. Indeed, cohesion policy successfully makes the EU very visible in regions and localities (Mendez and Bachtler, 2016).

\section{Structural Funds as a Europeanisation Tool}


Structural funding is given to EU regions that require financial assistance. This is also called 'cohesion', or 'convergence', aiming to bring about greater cohesion between EU regions through assisting economic convergence by shrinking the social and economic gap between rich and poor regions (Epsosti and Bussoletti, 2008; Ramajo et al., 2008), counteracting the centripetal forces which concentrate wealth in core regions, leaving others behind (Roberts, 2003). Areas with less than $75 \%$ of average EU Gross Domestic Product (GDP) receive the highest levels of structural funds. In the United Kingdom, currently (as of 2017) West Wales and the Valleys; and Cornwall and the Isles of Scilly receive this level of structural funding. Other previous beneficiary regions include South Yorkshire, Merseyside, and the Highlands and Islands of Scotland.

There has been much debate around the effectiveness of structural funding. Rodriguez-Pose and Fratesi in 2004 note that the real gains were to be made in terms of human and social investment; and regions which are significantly less developed than their neighbours may find themselves vulnerable to 'poaching' of funds by those with greater capacity (Breidenbach et al., 2016). Indeed, there is evidence that structural funding works best in more socially and economically developed regions (Crescenzi and Giua, 2016), which may be because improvements can be better embedded within existing regional knowledge systems (Rodriguez-Pose and Crescenzi, 2008). Indeed, studies have found place-based forms of development which address regional specificities and are tailored to human, material and social capital to be especially beneficial (Camagni and Capello, 2015), particularly for supporting peripheral economies (Barca et al. 2012). In a similar vein, a positive impact of structural funding is associated with the ability of regional policy makers to properly address the needs of the region (Dotti, 2015). However, other research finds that whilst funds can be very effective at improving regional performance (Giua, 2014; Becker et al. 2010), these improvements are stronger when not limited to growth in GDP (Ferrara et al. forthcoming).Development may not be sustainable and regional performance drops strongly when funds are removed (Barone et al., 2016; Di Cataldo, 2016).

In policy terms, structural funding falls under the Europe of the Regions strategy which translated into what Keating (2008) calls 'The New Regionalism', circumventing national governments (who may still act as co-ordinatory bodies for delivering the funding) by concentrating poverty alleviation measures directly on European regions. Regional identity is encouraged and supported as both for differentiation in the global marketplace (Herrschel, 2010), and as a means of supporting the development of social capital, skills and networks within a region (Willett, 2013). This has meant that over recent decades, regional identification has become stronger across the EU (Willett and Tredinnick-Rowe, 2016; Hepburn and Elias, 2011), which was a contentious issue by Eurosceptics who privileged a more national basis of primary identification.

This hints at a potential series of tensions between and within beneficiary regions. Regions and nations that are struggling economically are tending to look to the culturally available imagined comfort of the nation state in order to deal with a difficult present (Polyakova and Fligstein, 2016; Arzrout and Wojcieszak, 2017). Moreover, whilst cohesion policy should present itself as a form of soft power assisting the Europeanisation process (Dabrowski, 2012), the use of such soft power is dependent not only on actual performance, but also on how EU institutions are perceived by people in these regions (Hooghe and Verhaegen, 2017). Consequently, understanding why structurally funded regions in the UK voted to leave the EU is a much more nuanced set of questions than asking only whether regions have benefitted from the investments made or not. Instead, it incorporates a 
whole range of understandings, beliefs, and values which need to be understood in order to know how structural funds can be used more effectively to achieve social, and not just economic cohesion. Next, we turn to the case study of Cornwall and the Isles of Scilly in order to understand this better.

\section{Cornwall and the Isles of Scilly}

Cornwall and the Isles of Scilly (IOS) is with West Wales and the Valleys, one of only two regions in England and Wales that still receive the highest levels of structural funding, and in both locations the majority of voters voted to Leave. In Cornwall and the Isles of Scilly, $56.5 \%$ voted this way, and only two districts in the region voted overall to remain. What makes this surprising (and Cornwall an interesting case study), is that unlike in other regions, Cornwall actively campaigned for nearly a decade to receive the funding in the first place (Willett, 2013), and has received much support from the European Union. Indeed, development metrics indicate that structural funds have had a very positive effect on the Cornish economy (Di Cataldo, 2017).

In the early 1990's Cornwall and IOS were in a NUTS 2 region with neighbouring Devon. Devon's comparative wealth statistically hid post-industrial Cornwall, which solo had a GDP of $69 \%$ of the EU average, falling well below the cut off $75 \%$. Therefore in 1992, instead of receiving the highest level of Objective 1 funding, Cornwall had to settle for Objective 5b (Deacon, Cole and Tregidga, 2003). This initiated a high profile campaign which involved politicians and decision makers at all levels (Willett, 2013). Although it might appear as if Cornwall should naturally receive Objective 1 on account of its economic statistics, powerful embedded interests were opposed. Often this rested on the grounds that Cornwall and Devon combined provided a stronger lobbying voice (Stayner, 1997), or that it was not a 'natural' economic unit (Gripaios and Bishop, 2006). Interestingly and echoing the importance of identity under the Europe of the Regions agenda, a key factor underpinning the decision of the EU to grant Cornwall NUTS 2 status was the strength of local cultural identity (Willett, 2013). Indeed, the Single Programming Document outlining what was to happen under the duration of the 1999-2006 award was strongly aware of the regional importance of Cornwall's Celtic heritage and unique identity (Government Office South West, 1999).

The importance of the EU for protecting Cornwall's cultural heritage makes the Brexit vote even more interesting. Whilst there is an EU wide shift towards seeking protection from a changing world in national governments; stateless nations, sub-state nations, or regions seeking autonomy and selfdetermination have found the EU to be a stronger protector of their interests (Anderson and Keil, 2016; Hepburn and Elias, 2011). Cornwall has direct experience of this, and the EU has been a reliable protector of Cornwall's national identity, ethnicity and language. Most recently this has been through its recognition as a national minority by the European Framework Convention for the Protection of National Minorities (Willett and Tredinnick-Rowe, 2016). Moreover, Cornwall also has a long history of seeing the nation state as neglective at best, and oppressive at worst, rather than as a means of support (Willett 2013).

Nevertheless, Cornwall is still one of the poorest parts of the UK, with earned incomes and higher level skills falling well below UK averages (NOMIS, 2017). As such, it mirrors much of the poverty and uncertainty over the future (Willett 2013) that is characteristic of regions exhibiting a strong Brexit vote (Arnorsson and Zoega, 2016; Goodwin and Heath, 2016; Ingehart and Norris, 2016), although as Dorling (2016) points out, poverty alone is not an adequate explanation Consequently, a more nuanced analysis needs to understand why the identity-based factors behind the Brexit vote in 
Cornwall trumped the identity based factors behind its relationship with the EU; how the nation state became a source of support rather than neglect or oppression; what this tells us for future structural funding programmes in order to achieve better cohesion and integration; and what this means for future regional development programmes in the UK.

\section{Method}

To differentiate our study from existing analyses of Brexit voters (DiCataldo, 2017; Inglehart and Norris; 2016; Goodwin and Heath, 2016), we chose to use a deeply qualitative approach, rather than rely on large data-set and expert inferences. This study directly explores the perceptions of voters themselves, using a combination of focus groups, one-to-one interviews, and a qualitative survey. We collected data between January-April 2017. In common with a grounded theory approach to qualitative research more broadly (Charmaz 2006; Strauss and Corbin 2008), our object was not to make generalisations about all Leave voters in Cornwall, but to understand the ways that the Leave voters in our study talked about and rationalised their voting decision. For this, we needed to sample a wide range of opinions and beliefs. We began with in depth conversations with persons who reached their voting decision from a position of deeply informed choice, using our interviews and focus groups to inform the qualitative survey. This method enables our study to nuance or challenge some of the assertions about Leave voters intentions (Inglehart and Norris; 2016; Goodwin and Heath, 2016; Curtice 2017) and apply it directly to implications for economic development.

Many participants felt very self-conscious about how others might perceive both their vote, and their rationale for their decision. Some felt that they may be perceived as 'racist' or unintelligent, as a result of voting 'Leave'. One participant stated, "A lot of remainers say I'm thick or uneducated for voting to leave..." Consequently, we also included 9 semi-structured interviews to accommodate individuals who did not feel comfortable discussing their vote in a group situation (Flick 2006). Questions were very similar to those used in the focus groups.

We conducted 3 focus groups totalling 15 participants, across Cornwall. Initially, leave-voting participants were recruited from within the business and Cornish cultural communities. The business leaders were interesting because we imagined them to have a better than average practical understanding about structural funding within the region. Indeed, some had received structural funding for their enterprises. This enabled us to consider the complexities within a narrative that was both well informed, but acted against its apparent interests. The latter group were a strong starting point because of the deep connection mentioned above, between Cornish cultural campaigning and a pro-EU stance. Here too, understanding the tensions within this complex narrative enabled us to ask more searching questions in the qualitative questionnaire. Later, we used snowball sampling (Flick, 2006) for a final group of similarly informed participants. Perhaps also attributable to the high profile nature of structural funding in Cornwall, participants did tend to know that Cornwall received this EU support. Similar to Dorling (2016), many of the 24 Leave voters interviewed were well educated, had professional careers, and were well-connected, challenging 'left behind' explanations for the Leave vote.

Participants were asked to discuss why they voted 'Leave'; whether structural funding may have impacted upon their decision; the extent to which leaving may impact upon Cornwall and other geographic areas, and whether regional identity may have affected thier decision. The focus groups and interviews generated rich, detailed data from a relatively high number of participants. It enabled 
the identification of common themes; discourse and narratives amongst 'Leave' voters within Cornwall, as opposed to providing an extremely detailed and completely accurate account of the perspectives of a very small number of voters (Flick 2006).

The final phase of the primary fieldwork took the form of a qualitative survey of largely open questions, drawing on the interviews to provide categories for further exploration. This was not designed as a representative sample, but provided a means of collecting narrative responses from of a broad cross-section of Leave voters. The survey was shared amongst social media, and the email lists of business, local government, and cultural organisations. In addition to demographic details, participants provided anonymous responses to a series of questions focused upon their perceptions of the EU and why they voted 'Leave'. The survey received over 820 unique responses over a 4-week period, including Remain voters and incomplete responses. Complete responses from Leave voters (on which this analysis is based) numbered 287 and was used to identify the broad themes amongst 'Leave' voters that we discuss below. Qualitative responses from the survey and interviews were imported into Nvivo, which highlighted the most popular words and themes. We analysed this data with regards to the phrases used by participants in the interviews and the survey, to explore the narratives that they developed. A sample of the focus group and survey voices are used below to illustrate our findings.

\section{Research Findings}

Participants provided many different reasons for voting Leave. Some will be familiar, however we found important nuances to at times familiar tropes. A great deal of attention has focused upon the suggestion that Leave voters were primarily motivated by a desire to reduce immigration (Travers, 2016). This message was widespread across a range of media channels before and after the referendum. Our data suggests that voters' rationale was far more complex and multi-faceted than this. Immigration was one of the most commonly cited factors for wishing to leave the EU, but participants that referred to immigration were primarily concerned about earning enough money to 'live a decent life'; the general cost of living, and their perceived inability to access public services, such as the NHS. It was commonly mooted that a reduction in immigration would make it easier to access essential public services and earn a living. Similarly, a strong desire to 'regain control' includes, immigration; borders; UK legislation and decision-making. One participant explained that; "We should have a say on what goes on in our country, instead of paying someone to dictate to us." Another commented, "Us... The people of Britain should be allowed to say what is best for our country."

The findings presented below are arranged in terms of the analytical themes identified by the software. These are Money; Public Services; Immigration; Infrastructure; Local Business or Industry; Taking Back Control; and Regional Identity. Many of these themes do not directly relate to areas addressed by the structural funding programme. However, these were matters which deeply concerned participants. That structural funds did not engage with these topics enabled participants to follow the Leave line of 'it's not EU money, it's our money' referring to what is perceived as an overly large contribution that the UK makes to the EU. Indeed, for some participants, the fact that structural funds did not address these issues that were so important to them, meant that they were able to 
believe that economic development would be better and more accountable if it was funded and delivered by the UK government. This can be read as an indication that when development policies do not address place-based issues and local concerns and specificities (Barca et al 2012; Camagni and Capello 2015), local residents may be more inclined to overlook the benefits of funding, or interpret it as being spent on the wrong things. Worse than this, in believing that EU funding did not meet their particular needs, participants often overlooked the negative narrative that they had constructed about EU support.

\section{Money}

Money was the most commonly cited issue amongst participants from a range of socio-economic and educational backgrounds. Inequality was another frequently discussed concern. As previously discussed, Cornwall is a significant beneficiary of EU funding. Despite this, participants held mixed views on the extent to which they felt that leaving the EU may impact upon Cornwall. Some said that they felt that the withdrawal of EU funds would likely have a negative impact upon wealth and employment within Cornwall. Others did not perceive that EU funding helped them at all, so it was unimportant. The director of a local engineering firm explained, "Losing this funding won't do any harm to the county. We are spending so much on the EU and only getting a fraction of that money back. How can we be worse off if we aren't spending this money?" He subsequently said that he felt that the money should simply be given 'straight to those that need it'. This statement proved to be popular amongst the other five participants in this focus group.

Another participant illustrated this point by stating that he felt that paying a sum, such as $f 2$ million, to the EU would result in the receipt of a far lesser net gain, perhaps of $£ 1$ million. He felt that this was the inevitable result of the costs and financial inefficiencies involved in the administration of such a large organization. Consequently, it was imagined that the loss of EU funding would result in more money being available from the UK government. On a similar note, the data showed that the faraway offices of the European Parliament were often regarded as an expensive and inefficient waste of time, as participants could see little evidence of impact within their local area. We see here that rather engender some kind of loyalty to the EU for the funding that Cornwall has received (Mendez and Bachtler 2016; Dabrowski, 2012), many participants had merely reinterpreted the funding as being ineffective or inefficient. This is not related to the actual data about the benefits of structural funds (Crescenzi and Giua, 2016), but is an ideational claim, based on personal perception, which contradicts empirical findings (Di Cataldo 2017).

Participants often felt great concern and compassion for others within their local area. They frequently referred to examples of specific people that were struggling to earn enough to pay their bills or waiting for a lengthy period of time to access hospital treatment for medical conditions. These examples were often used to explain or justify why they felt that EU funds could be better spent elsewhere. One female participant in her sixties commented that, "We need to help our own people first." This was a widely held sentiment within the sample, thus suggesting that those within regions that are struggling economically may look to the culturally available imagined comfort of the nation state in order to deal with a difficult present (Polyakova and Fligstein, 2016; Arzrout and Wojcieszak, 2017). Indeed, we start to see here some kind of reconfiguration of the spatial scale to which 
participants felt an affinity, and we find that the face-to-face contacts of locality provided an important underpinning for why the 'remote' and 'faceless' EU was able to be constructed as an outsider to participants' identities.

\section{Public Services}

The availability of public services was commonly cited within the research. Social policy is neither a structural funding concern, nor an EU competency. However, it did underpin participant's discussions, especially with regards to immigration. We found that many participants felt that six years of austerity and public sector cuts had had a significant impact upon the kinds of public services that are available, and when they are available. People did not tend to perceive that a limited availability of public services is the result of EU immigration. Instead, they simply hoped that a vote to leave the EU would impact upon the number of people in need of public services in the future and ultimately, ensure easier access to these scarce resources, thus making their own lives slightly less difficult. One participant said, "Controlling immigration will mean better forward planning for medical services, housing and schooling."

Discussion in one focus group centred around the suggestion that the EU should fund public services, such as the NHS. A male in his fifties commented, "They've funded a few road signs and a load of art things, but we need help with the NHS and schools... We're throwing money away on the wrong things." This sentiment was widely reported within the focus groups, interviews and the qualitative survey. It is important to note that education, housing, and the NHS form an important part of the national political discursive landscape, which may go on to represent symbolic markers in a more national, rather than regional identification, countermanding the Europeanisation of Structural Funding (Kouri, 2014).

\section{Immigration}

A great deal of national media discourse focused on immigration and the suggestion that a vote to leave the EU was a vote against immigration and freedom of movement. But there was very little discussion of immigration within the focus groups or the face-to-face interviews. Participants were keen to emphasize a range of reasons for voting to Leave. Despite this, immigration was widely cited within the qualitative survey data. Crucially, it was often referred to alongside some other reason, such as the aforementioned 'overstretched' public services; difficulties in obtaining skilled employment or affordable housing. Very few respondents said that a desire to reduce immigration was their only reason for voting Leave. Consequently it appears that immigrants may have become a scape-goat or 'other' acting as a repository for the difficulties faced by British people. This has implications for British public and social policy, contributing to an increased support for nationalist policies and a rise in Eurosceptism (Arzrout and Wojcieszak, 2017; Polyakova and Fligstein, 2016) by delineating the nation and citizenship as the boundary between 'insiders' and 'outsiders'. This countermands Europeanising forces such as Structural funding (Kouri, 2014; Dabrowski 2012; Mendez and Bachtler 2016), but is consistent with the shift for struggling persons to look to the nation as a form of support ((Arzrout and Wojcieszak, 2017; Polyakova and Fligstein, 2016). 
A number of participants felt concern that many European countries have abolished internal border control. They noted that this was an EU policy and expressed fear that this is enabling terrorists or criminals to travel easily across the EU. Perhaps the most interesting point about this example lies in trying to understand what lies underneath that fear, that attaches itself to immigration, and then to the EU. A common cross-cutting theme emerging from this lies in a sense of insecurity about the present and the future, which then manifests itself in Eurosceptic (and nationalistic) discourses.

\section{Infrastructure}

Improving infrastructure is at the heart of what structural funding is designed to achieve, and so it is a surprise that this also emerged as a theme. Many participants did not seem to have an awareness, understanding, or appreciation of the level of infrastructural investment that has come through the EU. Alternatively, it might have been that to acknowledge the importance of EU work in this area was too big a challenge to the anti-EU narratives that they had constructed. Instead, survey participants frequently noted that the EU failed to address issues that are important to them, including road improvements; accessible rail travel and the provision of affordable housing. Whilst affordable housing is not commonly part of structural funding programmes, the EU has contributed significantly to road building and rail travel in the region (ERDF Convergence 2018). On the converse, participants found it easier to list projects that they thought ought not to have been funded. In the qualitative survey participants frequently struggled to name Structurally funded projects, or often could only name projects that reinforced a perception that the projects were 'an unmitigated waste of money'.

We can take two things from this. Firstly, that there may be a problem with how investments have been communicated in the area, and also that there may be an element of choice with regards to what information individuals pick up on. For example, the fact that some projects have become totemically used as evidence of the inefficiency of structural funds is perhaps less interesting than the way these anti-EU narratives are generated and then used.

\section{Local Business or Industry}

A number of participants expressed sadness or disappointment that Cornwall's traditional industries, including fishing, farming and mining, had experienced decline over the last few decades. Similar to Infrastructure, the most interesting thing about this theme lies in understanding the narratives that are developed. Many within the fishing community said that they voted Leave because they felt that EU fishing quotas and the associated legislation make it more difficult for local fishing businesses to operate profitably. The owner of a small fishery commented that he had received $£ 80,000$ worth of EU funding, but was unable to spend it in an impactful way, as he had to meet strict criteria imposed by the EU. As a result, he felt that the EU was likely to be 'wasting money' in numerous areas. Another member of the fishing community expressed frustration at EU legislation, "If we had our way then we would have international limits for fishing. Keep all of the French boats out. There are more French and Belgian boats fishing than us. We need to take back control of our waters, so that we have enough money and so that we're not giving it all to Europe."

Furthermore, many participants from the farming sector said that they believe EU regulations impact 
negatively upon their business. One farmer said, "The EU require so much paperwork just to be able to move cattle from one farm to another. It means that farming isn't enjoyable like it was 30 years ago." Another provided examples of specific farmers over the age of 80 years who were struggling to update the necessary records online. She noted that these people had never used the Internet before and that they had to pay another person to complete this, creating extra work and expense. She said that she believed that this was the result of EU legislation.

In terms of narrative, firstly we see a nostalgic emphasis on traditional industries, which have arguably a lesser impact than on newer but less romanticised enterprises in digital technologies, manufacturing, and the creative sector. Similar to Infrastructure, this suggests that the impact of the EU on industry is selected in order to support a particular narrative which has already been decided upon. Consequently, this is less an indication of failure of funding, but more a suggestion of the paucity of counter-narratives challenging the traditional, and Eurosceptic nationalist view (Curtice 2017). It is perhaps also symptomatic of the conservatism and traditionalism behind the Brexit vote (Inglehart and Norris, 2017; Kauffman, 2016), that traditional industries have been emphasised at the expense of emerging new sectors, funded by the EU.

\section{'Taking Back Control'}

In common with the national debate, 'Taking back control' and 'sovereignty' was a key theme across the data. Participants frequently claimed that the EU 'forces' laws and policies upon the UK or that the UK Parliament fails to adequately scrutinise legislation from the EU before implementing it. They felt that an increase in control would improve life for many within the UK. We see the UK presented as vulnerable to a dominating EU. As a result, not only are citizens in need of protecting by the nation state, but the nation state is also in need of protection by its citizens. This initiates a relationship of reciprocity between state and nation, facilitated and supported by other factors. It also provides an interesting rehabilitation for the 'oppressive' nation state that we see in the campaign for Cornwall to receive structural funding (Willett, 2013; Deacon, Cole and Tregidga, 2003). Instead, the nation state is being oppressed by a dominating supra-national entity.

Participants were asked to consider the three main issues facing Cornwall; the UK and also, the EU. Frequently participants claimed that the UK and Cornwall share common issues, such as the need to increase employment; struggles with the cost of living and an 'overstretched' public sector. Conversely, the EU is imagined to face - different issues, including enabling the free movement of people and goods; encouraging trade and developing legislation. Consequently, participants tended to align themselves with the nation as a locus of identification, rather than the region or the EU.

Often participants claimed to feel that politicians did not listen to 'ordinary people' like them. One noted, "I was sick of the political elite making decisions that benefit them. The rich just get richer and the poor just get poorer. I voted for us to leave because something needs to change." Others felt slightly less strongly about the issue. One female participant in her twenties acknowledged, "The most important thing is that we have our ability to make our own mistakes and can put them right. We don't currently have that ability." Here we see 'taking back control' referring to the (previously powerless) individual taking control over neglectful elites, and in people's minds, this may have 
become combined with a belief that policies were not place-based (see Camagni and Capello 2016; Barca et al 2012) and did not pay sufficient attention to what they saw as local priorities.

\section{Regional Identity}

The 'New Regionalism' of the 1990's and early 2000's saw a growth in the importance of the region (Keating, 2008) as a part of the Europeanisation process. This places regional identity at odds with national identification within the context of the European agenda. For Cornwall in particular, regionalism has led to a significant growth in the importance of Cornish identity within Cornish civil society (Willett and Tredinnick-Rowe, 2016). However we also see a resistance to that too, and within this project some participants' national identity played a more significant role in their decision to vote Leave than their Cornish or regional identity. Few participants felt that Cornwall faced vastly different issues to the rest of the country, and maybe as a part of this were able also to ignore the significant differences of the Cornish economy. Furthermore, many referred to being British, but perhaps only two or three referred to being Cornish. One male participant laughed when asked about the significance of Cornish nationalism. He commented, "Plenty of idiots want Cornwall to become its own nation... With proper pasties, proper turnips and proper Cornish beef." Most were not this disparaging of regional identity, but this does illustrate its lack of significance in the voter decision-making process.

If anything, the regionalism of the past few decades becomes another threat to the British or English nationalism threading many participant responses, rendering the nation state more vulnerable, and therefore in need of protection from its bullying (EU) Other. Current regional development policy encourages regions to differentiate themselves within the global marketplace (Herrschel, 2010; Willett and Tredinnick-Rowe, 2016), and vocal regions may be a key means of countering the centripetal effects of contemporary western economies (Roberts, 2003; McCann, 2016). However whilst there are sound operational reasons, it does raise the ongoing challenge between how to structurally and discursively negotiate the changing relationships between regions, nations, and supra-national bodies, in ways that are not perceived to enfeeble some of these institutions. A (British or English) nationalist backlash might be an obvious result of a feeling of threat from above (the EU) and below (the UK). For structural funding and Europeanisation, it is interesting how arbitrarily lines of identification are drawn.

\section{WHAT DOES THIS MEAN FOR FUTURE DEVELOPMENT}

The receipt of a significant amount of structural funding should have garnered a sense of loyalty towards the EU (Kouri, 2014; Mendez and Bachtler, 2016; Dabrowski, 2012) that mitigated British Euroscepticism (Curtice 2017). That it did not, indicates a need to understand why voters were able to either claim a lack of knowledge about the funds, or to argue that they had been ineffective despite contrary evidence (Di Cataldo 2017). To do this, we look at the narrative that our respondents developed.

We found two dominant narratives. Both were based upon a desire for security and stability. The first was nostalgic for the perceived safety of the (pre-EU) past (see also Inglehart and Norris, 2017; Kaufman, 2016), and which might be reflected in the emphasis on traditional industries. This group 
commonly expressed fondness for the British Empire; a strong army and were very patriotic, and felt less trusting of other EU citizens(See also Kaufman, 2016). These kinds of uncertainties mean that such individuals are less likely to have the trust (Hooghe and Verhaegen, 2017) and openness (Curtis, 2016) required for post-national forms of identification. Consequently, a regional threat to a national identity might actually reinforce the nationalism borne of current insecurity.

The second narrative was set within the context of scarce resources and austerity. Interview participants commonly expressed fear that their children would not be able to afford a home of their own; difficulties finding a job that pays the bills; concern over the difficulty of seeing an NHS doctor when unwell; and fear that there would be no social care to help them in old age. They perceived that leaving the EU may lead to a reduction in immigration and thus, less competition for these scarce resources. This also represents a return to the nation state as a locus of protection in an uncertain world (Arzrout and Wojcieszak, 2017; Polyavova and Fligstein, 2016) even as the nation state is also imagined as requiring protection.

We also see that through a combination of perceptions about the delivery of structural funding and national level discourses about the EU, the Leave voters interviewed tended to construct the EU as a hierarchical, bullying Other, with little commonality of identity with the UK. Under this discourse, both the UK and the citizen needs to be protected from an institution that only helps elites, at a time when people feel a real threat and challenges to their standard of living and access to essential services. It is this situation which underpins the statement to 'take back control'. Current (elite, and by implication, EU) decision makers are not imagined as capable of making decisions which benefit ordinary people, and so consequently regaining 'control' is imagined as a means of ensuring that policy better benefits them. This raises the key question about how to develop structural funding policy in which people feel and perceive the measurable benefits that structural funding has (Di Cataldo, 2017.

Our first observation is that development policy is imagined by interviewees as being a series of hierarchical layers, in which the people at the bottom (the citizen) have been neglected. We need to stress that this is not actually about more, or better communication and media presence per se. One of the key issues is that citizens have not found ways to engage on an intellectual or emotional level with the projects, which enabled them to develop narratives which combined Euroscepticism and a lack of accurate understanding about the EU (Curtice 2017), with a frustration that their needs were not being met. This facilitated a belief that it was the EU's fault that these needs were not met. We suggest addressing this through a greater emphasis on co-development of project ideas, and participatory projects. Involving people as equal partners in the development of their region may be a way of both improving awareness about the types of projects which are funded, but also might improve their sense of agency and thereby approval of development plans (Willett and Lang 2018). We anticipate that a more collaborative and participatory approach may help to reduce some of the antagonisms within the Othering processes which set some parts of the system against each other, softening dividing lines, and removing opportunities for 'victim' status. Enhanced participation in local and community government may be a way of doing this.

Furthermore, we recommend a stronger emphasis on place-based strategies (Camagni and Capello 2015; Barca et al 2012). Practically, this might mean extending the definition of infrastructure to 
include a greater emphasis on social capital (such as knowledge, skills, and networks - see Atterton, 2007) within the community. At present, this is partly achieved through the European Social Fund, but might be extended to a more 'community development' angle that utilises aspects of participatory and deliberative democracy, in order to help to increase community involvement, thus aiding development visibility on a day-to-day level. It was striking how important the immediate community was to participants, whilst also retaining a strong sense of national identification. Developing social capital may also help to meet the way that participants wanted development to be seen to be supporting the most vulnerable in society. Indeed, there is evidence to suggest that improving regional knowledge systems through social capital will also help to better embed the improvements made on a more 'hard' infrastructure level (Crescenzi and Giua, 2016; Rodriguez-Pose and Crescenzi, 2008). On a structural funds basis, this might include the facility to be a little flexible in what counts as 'infrastructure' on a State by State basis. For example, in the UK, affordable housing might indeed be considered as important for infrastructural resilience of the labour-force.

\section{CONCLUSION}

While this case study does not seek to make generalisable claims about all Leave voters in Cornwall, the fact that (with the exclusion of Northern Ireland), the parts of the UK that received the highest levels of Structural Funding also manifested strong votes to Leave the European Union suggests that rather than contributing to both cohesion and Europeanisation, structural funding might have the opposite effect. The UK is highly unusual in structural funding terms as the UK government is currently the administrative and accountable body, regional policy needs to fit with national priorities, and the UK resisted embedding a European identity (Curtice 2017). However, important lessons can still be learned.

Firstly, whilst cohesion policy does have the ability to wield soft power from the top down (Kouri, 2014; Dabrowski, 2012; Mendez and Bachtler 2016), it also needs to engage and be perceived as engaging with individuals from the bottom up (Borzel and Risse 2012). This suggests an increased sense of accessibility between citizens and the EU, whether this be through the presence of the EU within the regions, or facilitating greater mobility between community level government across the $\mathrm{EU}$ and EU instituions. To a degree, the imagined remoteness of the EU (despite its impact on the region) facilitated its taking the place of the UK government as a significant Other in the Cornish discursive environment.

Secondly, a sense of the impact of funding not having met expectations might have been an important factor behind the Cornish vote. The sense of optimism following the Cornish campaign for Objective One (Willett, 2013; Deacon Cole and Tregidga, 2003) followed by Austerity cuts may have helped to create the environment through which the EU was more available to be easily constructed as the cause of present insecurity. Consequently, measureable positive impacts were not felt and experienced by our Leave voting participants. This is particularly something to be aware of given the strongly embedded way that the nation state is imagined as a primary locus of protection for the citizen (Arzrout and Wojcieszak, 2017; Polyavova and Fligstein, 2016). For development in general and structural funding in particular, this would suggest a stronger approach to participatory, place-based decision-making and involvement with regards to funded projects, with greater flexibility over regional 
[Type text]

priorities (Barca et al. 2012). The key is to ensure that citizens feel that development is a part of a process that they have contributed to and are partially responsible for, rather than one that has been 'done to' them without their consent. A skills pot to which individuals can apply to pay for courses to upskill would also help to encourage a sense of individual ownership of development monies.

Finally, we find that it would be a mistake to confine the Brexit vote in Cornwall to the popular stereotypes of the uneducated, the old, and the poor (Arorsson and Zoega 2016; Goodwin and Heath, 2016; Los et al., 2017). Our participants came from a broad range of backgrounds and demographics. Instead, our findings are more in line with the identity based, cosmopolitan versus communitarian type explanations for Brexit (Inglehart and Norris, 2017; Kaufman, 2016). In our study, we found a key theme whereby in the uncertainty that individuals experienced about their present, they were looking to a combination of nostalgic perceptions about the past or were specifically calling on the nation state and national identities to protect themselves from the threats and uncertainties that lay in the future. Indeed, this version of British or English nationalism drew the group together into a cohesive story, even if it excluded half of the other members of the polity. This rests on a deep sense of insecurity and lack of control, which must be addressed at a policy level if Britain is to regain a more united sense of citizenship.

\section{References}

Anderson P and Keil S (2016) Minority Nationalism and the European Union: The Cases of Scotland and Catalonia. Le Europe en Formation 379: 1-18.

Arnorsson A and Zoega G (2016) On the Causes of Brexit. CESifo Working Paper Series, No.6056. Munich: CESifo.

Atterton J (2007) The 'Strength of Weak Ties': Social Networking By Business Owners in the Highlands and Islands of Scotland. Sociologia Ruralis 47 (3): 228-245.

Arzrout R and Wojcieszak M (2017) What's Islam got to do with it? Attitudes towards specific religious and national out-groups, and support for EU policies. European Union Politics 18 (1): 51-72.

Barca F, McCann P and Rodriguez-pose A (2012) The Case For Regional Development Intervention: PlaceBased Versus Place-Neutral Approaches. Journal of Regional Science 52: 134-152

Barone G, Francesco D and De Blasio G (2016) Boulevard of Broken Dreams: The End of EU Funding in Italy (1997: Abruzzi, Italy). Regional Science and Urban Economics 61: 31-38.

Becker S, Fetzer T and Novy D (2016) Who voted forBrexit? A comprehensive district-level analysis. Retrieved from http://ukandeu.ac.uk/research-papers/who-voted-for-brexit-a-comprehensivedistrict-level-analysis/ (accessed 11 August 2017).

Borzel T and Risse T (2012) From Europeanisation to Diffusion: Introduction. West European Politics. 35(1):1-19

Breidenbach P, Mitze T and Schmidt C M (2016) EU Structural Funds and Regional Income Convergence: A Sobering Experience. Ruhr Economic Papers No.608. Dortmund: Ruhr Economic Papers. 
[Type text]

Esposti R and Bussoletti S (2008) Impact of Objective 1 funds on regional growth convergence in the European Union: A panel-data approach. Regional Studies 42(2): 159-173.

Camagni R and Capello R (2015) Rationale and Design of EU Cohesion Policies in a Period of Crisis. Regional Science Policy and Practice 7:25-47

Charmaz K (2006) Constructing Grounded Theory: A Practical Guide Through Qualitative Analysis. London: Sage Publications

Crescanzi R and Giua M (2016) The EU Cohesion Policy in Context: Does a Bottom-Up Approach Work in All Regions? Environment and Planning A 48 (11): 2340-2357.

Curtice J (2017) Why Leave Won the UK's EU Referendum. Journal of Common Market Studies 55:1937.

Curtis K (2016) Personality's effect on European Identification. European Union Politics 17 (3): 429-456.

Dabrowski M (2012) Shallow or Deep Europeanisation? The Uneven Impact of EU Cohesion Policy on the Regional and Local Authorities in Poland. Environment and Planning C: Government and Policy 30: 730-745.

Deacon B, Cole D and Tregidga G (2003) Mebyon Kernow and Cornish nationalism. Cardiff: Welsh Academic Press.

Di Cataldo M (2016) Gaining and Losing EU Objective One Funds: Regional Development in Britain and the Prospect of Brexit. LSE 'Europe in Question' Discussion Paper Series No. 120. London: LSE.

Di Cataldo M (2017). The impact of EU Objective 1 funds on regional development: Evidence from the U.K. and the prospect of Brexit. Journal of Regional Science 57, 814-839.

Dorling D (2016) Brexit: The Decision of a Divided Country. BMJ 354 i3697.

Dotti NF (2015) Unwritten Factors Affecting Structural Funds: The Influence of Regional Political Behaviours on the Implementation of EU Cohesion Policy. European Planning Studies 24 (3): 530-550.

ERDF Convergence (2018). Investments. http://www.erdfconvergence.org.uk/investments/ Accessed 30.05.2018.

Ferrara AR, McCann P, Pellegrini G, Stelder D and Terribile F. (2016) Assessing the Impacts of Cohesion Policy on EU Regions: A Non-Parametric Analysis on Interventions promoting Research and Innovation and Transport Accessibility. Papers in Regional Science. Epub ahead of print 23 May 2016. DOI: 10.1111/pirs.12234.

Flick U (2006) An introduction to qualitative research. London: Sage.

Giua M (2014) Spatial Discontinuity for the Impact Assessment of the EU Regional Policy: The Case of Italian Objective One Regions. Roma Tre University Economics Department Working Paper Series No. 197. Rome: Roma Tre University Economics Department.

Government Office South West (1999). Cornwall and isles of Scilly Objective 1 Single Programming Document, 2000_2006. Bristol: Author.

Goodwin M and Heath O (2016) The 2016 Referendum, Brexit and the Left Behind: An Aggregate-Level Analysis of the Result. The Political Quarterly 87 (3): 323-332. 
[Type text]

Gripaios P and Bishop P (2006) Objective one funding in the U.K: A critical assessment.

Regional Studies 40(8): 937-951.

Habermas J (2017) Citizen and State Equality in a Supra National Political Community: Digressive

Proportionality and the Pouvoir Constituant Mixte. Journal of Common Market Studies 55 (2): 171-82.

Harris R and Charlton M (2017) Voting out of the European Union: Exploring the geography of Leave. Environment and Planning A. 48(11):2116-2128.

Hampshire-Monk I (1992) Modern Political Thought: Major Political Thinkers from Hobbes to Marx. Oxford: Blackwell.

Hepburn E and Elias A (2011) Dissent on the periphery? Island nationalisms and european integration.

West European Politics 34 (4): 859-882.

Herrschel T (2010) Growth and innovation of competitive regions: the role of internal and external

Connections. European Planning Studies 18 (7): 1169-1172.

Hooghe $M$ and Verhaegen S (2017) The effect of political trust and trust in European Citizens on European Identity. European Political Science Review. 9(2): 161-181.

Inglehart R and Norris P (2016) Trump, Brexit, and the Rise of Populism: Economic Have-Nots and Cultural Backlash. Available at: https://papers.ssrn.com/sol3/papers.cfm?abstract id=2818659 (accessed 11 August 2017).

Kaufman E (2016) It's not the economy, stupid: Brexit as a story of personal values. London School of Economics and Political Science (LSE). Available at: http://blogs.Ise.ac.uk/politicsandpolicy/personalvalues-brexit-vote (accessed 11 August 2017).

Keating M (2008) Thirty years of territorial politics. West European Politics 31(12): 60-81.

Klaus G (2017) Divided Sovereignty, Nation and Legal Community. Journal of common Market Studies 55 (2): 213-222.

Kouri M (2014) European Integration and Cultural Diplomacy in Times of Crisis: The Case of Greece. The Journal of Arts Management, Law and Society 44 (4): 218-233.

Los B, McCann P, Springford J and Thissen M (2017) The Mismatch between Local Voting and the Local Economic Consequences of Brexit. Regional Studies 51 (5): 786-799.

McCann P (2016) The UK regional-national economic problem: Geography, globalisation and governance. London: Routledge.

Mendez C and Bachtler J (2016) European Identity and Citizen Attitudes to Cohesion Policy: What do we know? COHESIFY RESEARCH PAPER 1

Nomis (2017) Labour Market Profile Cornwall.

https://www.nomisweb.co.uk/reports/Imp/la/1946157349/report.aspx?town=Cornwall (accessed 11 August 2017).

Polyakova A and Fligstein N (2016) Is European Integration Causing Europe to Become More Nationalist? Evidence from the 2007-9 Financial Crisis. Journal of European Union Public Policy 23 (1): 60-83. 
[Type text]

Radielli C (2004) Europeanisation: Solution or Problem? European Integration Online Papers. 8 (16).

Ramajo J, Marquez MA, Hewings GJD and Salinas MM (2008) Spatial Heterogeneity and Interregional Spillovers in the European Union: Do Cohesion Policies Encourage

Convergence Across Regions? European Economic Review 52(3): 551-567.

Roberts P (2003) Partnerships, Programmes and the Promotion of Regional Development: An Evaluation of the Operation of the Structural Funds Regional Programmes. Progress in Planning 59(1): 1-69.

Rodriguez-pose A and Crescenzi R. (2008) Research and Development, Spillovers, Innovation Systems and the Genesis of Regional Growth in Europe. Regional Studies 42(1): 51-67.

Smith A (1991) National identity. Harmondsworth: Penguin Books Ltd.

Stayner J (1997) The Janus Faced Periphery; Cornwall and Devon in the Twentieth Century. Policy and Politics 25 (1): 85-97.

Strauss A, Corbin J, Corin J (2008) Basics of qualitative research: Techniques and procedures for developing grounded theory. 2nd edn. Thousand Oaks: Sage Publications.

Travers T (2016) Why did people Vote for Brexit? Deep seated Grievances lie Behind this Vote, Available at: http://blogs.Ise.ac.uk/politicsandpolicy/why-did-people-vote-for-brexit/ (accessed 11 August 2017).

Willett J (2013) National Identity and Regional Development: Cornwall and the Campaign for Objective 1 Funding. National Identities 15 (3): 297-311.

Willett J and Rowe J (2016) The Fragmentation of the Nation State? Regional Development, Distinctiveness, and the Growth of Nationalism in Cornish Politics. Nations and Nationalism 22 (4): 768-785.

Zhang C and Lille N (2015) Industrial Citizenship, Cosmopolitianism and European Integration. European Journal of Social Theory 18 (1): 93-111. 